\title{
TRACE METAL DISTRIBUTION IN TISSUES OF CICHLIDS (OREOCHROMIS NILOTICUS AND O. MOSSAMBICUS) COLLECTED FROM WASTEWATER-FED FISHPONDS IN EAST CALCUTTA WETLANDS, A RAMSAR SITE
}

\author{
Soumya CHATTERJEE 1* ${ }^{*}$ Buddhadeb CHATTOPADHYAY 1, S.K. MUKHOPADHYAY ${ }^{2}$ \\ ${ }^{1}$ Government College of Engineering and Leather Technology, Salt Lake City, Calcutta, India \\ ${ }^{2}$ Durgapur Government College, Durgapur, West Bengal, India
}

Chatterjee S., Chattopadhyay B., Mukhopadhyay S.K. 2006. Trace metal distribution in tissues of cichlids (Oreochromis niloticus and O. mossambicus) collected from wastewater-fed fishponds in East Calcutta Wetlands, a Ramsar site. Acta Ichthyol. Piscat. 36 (2): 119-125.

\begin{abstract}
Background. Metals discharged in wastes from different industries into wetland ecosystems pose a serious threat to the receiving environment. Biotic components grown in the area amass such metals within their body through nutritional uptake and accumulation. The present investigation was carried out to study the extent of accumulation of different waste metals in tissues of cichlids commonly cultured in composite industrial wastewater-fed fishponds (Bheris) in East Calcutta Wetlands (ECW), a Ramsar site in India.

Materials and Methods. AAS studies were employed to estimate metal ( $\mathrm{Cr}, \mathrm{Mn}, \mathrm{Fe}, \mathrm{Cu}, \mathrm{Zn}$, and $\mathrm{Pb}$ ) concentrations in water, and bottom sediment of fishponds and fish tissues (gill, liver, muscle, and bones) of cichlids: Nile tilapia, Oreochromis niloticus L. and Mozambique tilapia, O. mossambicus (Peters, 1852), collected from contaminated and control sites.

Results. The concentrations of metals in bottom sediment were found higher than those of the overlying water. It was evident from the experiment that, either bone or liver was the site of maximum accumulation for the elements while muscles were the site of least metal accumulation in both fish species. Chromium, which was a highly publicised contaminant of tannery effluents, showed a similar distribution pattern (muscle $<$ gill $<$ liver $<$ bone) in these fishes. Concentrations of non-essential metals like $\mathrm{Pb}$ were highest in Nile tilapia liver $\left(17.9 \mathrm{mg} \cdot \mathrm{kg}^{-1}\right)$ followed by Mozambique tilapia liver $\left(14.7 \mathrm{mg} \cdot \mathrm{kg}^{-1}\right)$. Principal component analysis with Varimax rotation revealed that $\mathrm{Fe}$ and Mn were in the first and second component, respectively, to influence metal uptake and bioaccumulation.

Conclusion. Tissue-specific and species-specific patterns of metal concentration and partitioning were apparent from our experimentation. Dendrograms showed two definite clustering pattern, gill and muscle in one cluster with bone and liver in the other, two important organs so far as partitioning (in bone) and detoxification (in liver) were concerned.
\end{abstract}

Keywords: fish, Cichlidae, Oreochromis niloticus, Oreochromis mossambicus, heavy metals, wastewater, East Calcutta Wetlands, Ramsar site

\section{INTRODUCTION}

Industrial wastes are considered critical factors for disturbing the natural environment. Composite effluents tainted with different heavy metals are major environmental pollutants of varied wetland ecosystems (Wong 2003). Spread over 12500 ha, The East Calcutta Wetlands, a Ramsar site in West Bengal, India (lat 22 $33^{\prime}$ $-22^{\circ} 40^{\prime} \mathrm{N}$, long $88^{\circ} 25^{\prime}-88^{\circ} 35^{\prime} \mathrm{E}$ ), receives industrial runoff from at least 6000 large- and small-scale industrial establishments (including tanneries) and Calcutta metropolitan city wastewater throughout the year. The huge amounts of composite, heavy-metal-contaminated efflu- ents (nearly $50000 \mathrm{~m}^{3} \cdot \mathrm{d}^{-1}$ ) that flow down through a web of canals into the wetlands are also utilized by local farmers in pisciculture. Nearly 10915 metric tons of fish were produced annually in 286 large wastewater fed fishponds (Bheris), over $30 \%$ of total wetland area (Chattopadhyay et al. 2002). Among several cultivated species of fish, Nile tilapia, Oreochromis niloticus L., and Mozambique tilapia, O. mossambicus (Peters, 1852), are familiar for their high fecundity and fast growth rate. Tilapias are also known to occupy different physical and trophic strata of aquatic bodies and being dependent on varied food sources (Pillay 1993, Chattopadhyay et al. 2002). There- 
fore, these fish could be regarded as an indicator species in the context of ecotoxicology (Lin et al. 2005). The extents of accumulation of potentially hazardous metal contaminants in the tissues of fish cultured in some other contaminated areas in India and abroad are already on record (Jana and Sahana 1988, Canli and Erdem 1994, Kalay and Canli 2000, Mahmood 2003, Lin et al. 2005). In the present paper, concentrations and distribution of six metals namely $\mathrm{Cr}, \mathrm{Mn}, \mathrm{Fe}, \mathrm{Cu}, \mathrm{Zn}$, and $\mathrm{Pb}$ in different tissues of both Oreochromis niloticus and $O$. mossambicus of wastewater fed fishponds of the wetlands were investigated. The study on the accumulation pattern in different tissues in two species of cichlid, cultured in common ponds in the area would render a platform to understand the amount of non-essential toxic metal ions available within their body and the adaptability of the fish with the environment More importantly, this study would also help to compare the levels of different metals and sequestration within cichlid fish bodies collected from this large and unique urban wetland locale.

\section{MATERIALS AND METHODS}

The sampling stations were three fishponds located in and around the Chowbaga region, which was nearly $8 \mathrm{~km}$ from the source of the Storm Weather Flow (SWF) canal in the east Calcutta wetland ecosystem. In this site, municipal sewage is also mixed with the industrial wastewater of the canal, making it a composite effluent. This water has been utilized for fish production in large wastewater-fed fishponds through an indigenous practice of local farmers (Patnaik 1990).

Twelve fish samples (six Oreochromis niloticus and six O. mossambicus) were collected from three fish wastewater fed fishponds $(2 \times 2$ from one pond). Yearlings of fish specimens weighing $100 \pm 25 \mathrm{~g}$ were collected and dissected for gills, liver, muscles, and bones. Bottom sediments and water were also collected from the ponds. For comparison, twelve (six of each species) "uncontaminated" (uncontaminated from industrial wastes), control samples were also collected from two natural fishponds at Panduah, West Bengal, India (about $85 \mathrm{~km}$ north of the contaminated sampling sites) along with bottom sediment and water. Selection of elements for the study was carried out according to the major constituting elements that contaminate the concerned area as per the previous reports (Chattopadhyay et al. 2002).

All samples were prepared following standard protocols (Welz and Sperling 1999). Fish samples were dissected to collect different organs like gills, liver, bones, and muscles. Only gills were washed by Millipore water (18 $\mathrm{M} \Omega$ water from a Millipore water purification unit). About $10^{-15} \mathrm{~g}$ of the native organs were taken into Platinum crucibles and dried inside a Muffle furnace at $150^{\circ} \mathrm{C}$ for $3 \mathrm{~h}$. These were then cooled to room temperature and the dried weights were taken. These were then transferred inside the cooled Muffle furnace and slowly the temperature was raised to a range $500 \pm 50^{\circ} \mathrm{C}$ for $11 \mathrm{~h}$. The samples were removed and cooled inside desiccators to room temperature. $2.0 \mathrm{~mL}$ of concentrated $\mathrm{HNO}_{3}$ was added into the crucible and swirled, the acidified ash was gently warmed on a hot plate till evaporation of $\mathrm{NO}_{2}$ ceased and then heating was continued to evaporate the acid completely. The mass thus formed was transferred into the cool Muffle furnace once again. The furnace was gradually heated to a range of $450-500^{\circ} \mathrm{C}$ for $2 \mathrm{~h}$. Then the mass was cooled to room temperature. If the carbon still remained, then the process was repeated once again until white coloured ash was obtained. $10 \mathrm{~mL}$ of $1.0 \mathrm{~N} \mathrm{HCl}$ was added and the mixture was gently warmed until a clear solution was obtained. These were then cooled and transferred into $25 \mathrm{~mL}$ volumetric flasks. Millipore water (18 $\mathrm{M} \Omega$ water from a Millipore water purification unit) was added up to the mark and stored inside an incubator at $20^{\circ} \mathrm{C}$.

About $200 \mathrm{~mL}$ of collected water samples were filtered through Whatman $0.45-\mu \mathrm{m}$ glass-fibre filter and transferred to acid cleaned $250 \mathrm{~mL}$ polypropylene bottles and then acidified with concentrated nitric acid to $\mathrm{pH}$ not exceeding 2.0. Bottom sediment samples were dried $(80 \pm$ $10^{\circ} \mathrm{C}$ for $10 \mathrm{~h}$ in a hot air oven), homogenized, and sieved for extraction of $\mathrm{Ca}, \mathrm{Cr}, \mathrm{Mn}, \mathrm{Fe}, \mathrm{Cu}, \mathrm{Zn}$, and $\mathrm{Pb}$ from dry ashes. About $1.0 \pm 0.05 \mathrm{~g}$ dried and grounded sediment sample (carefully weighed through analytical balance, Mettler AE240) was placed inside a silicone crucible and ignited in a Muffle furnace at $500^{\circ} \mathrm{C}$ for $3 \mathrm{~h}$. The ignited mass was cooled inside desiccators, and transferred into a $100 \mathrm{~mL}$ Borosil beaker. Inside the beaker was added 10 $\mathrm{mL}$ concentrated $\mathrm{HCl}$ (Merck India) and the suspension swirled. The suspension was kept inside a thermostat controlled water bath in a temperature range of $70-80^{\circ} \mathrm{C}$ for $1 \mathrm{~h}$. The supernatant was decanted and kept inside a 100 $\mathrm{mL}$ volumetric flask. This contains mostly alkaline earth metals. To the residue in the beaker $10 \mathrm{~mL}$ each of $\mathrm{HCl}$ (concentrated) and $\mathrm{HClO}_{4}$ (concentrated, $70 \%$ pure, Merck India), and few porous beads were added, and was evaporated to complete dryness over a hot plate. This process was repeated when necessary. The dried residue was dissolved completely by using minimum amount (few drops) of concentrated $\mathrm{HCl}$. This solution was then transferred to the same volumetric flask where previous extract containing alkaline earth metal extracts was stored. The flask were then made up to the mark by Millipore water (18 $\mathrm{M} \Omega$ water from a Millipore water purification unit) and stored inside a refrigerator. This extracts were analyzed for elements.

Atomic Absorption Spectrophotometry (Perkin-Elmer AAnalyst-100 with interfacing AAWinlab Software), using element-specific hollow cathode lamps in default condition, by flame absorption mode was used to approximate the metal concentration within samples. Metal standards recommended by Perkin Elmer were used beforehand the analyses of the samples for both checking the sensitivity of the instrument and calibration. Reference materials (water: SRM. 1643d estuarine sediments: 1646a, bovine liver: SRM 1577b) procured from the National Institute of Standards and Technology (NIST), were also prepared in 
the same way. Each time the concentration was determined using non-linear calibration with 3 replicates each and $3.0 \mathrm{~s}$ integration times. Principal component analysis with Kaiser Normalization and hierarchical cluster analysis displayed in the form of two-dimensional dendrogram were made using statistical software (Statistica for Windows, Version 5.1A, Statsoft Inc. 1996 and SPSS Release 10.0 1997).

All gravimetric analyses, reagents and standard preparations were made using Mettler AE 240 monopan electronic balance. Mettler Autotitrator DL 25 was also used when necessary.

\section{RESULTS}

Metal concentrations in fishponds: Metal concentrations of water (expressed in $\mathrm{mg} \cdot \mathrm{L}^{-1}$ ) and bottom sediment (expressed in $\mathrm{mg} \cdot \mathrm{kg}^{-1}$ of dry weight of the sample) of wastewater fed fishponds were presented in Table 1. It was apparent from our study that bottom sediment concentrations of all six elements studied had higher concentration levels than that of overlying water (Table 1). Fe concen- tration in bottom sediment of wastewater fed fishponds was found to be highest $\left(26630.5 \pm 7145.31 \mathrm{mg} \cdot \mathrm{kg}^{-1}\right)$ among all other elements. In overlying water of the ponds, the Fe concentration was recorded as $3.1 \pm 1.12 \mathrm{mg} \cdot \mathrm{L}^{-1}$. $\mathrm{Zn}$ had the highest concentration in water of the wastewater-fed ponds $\left(6.1 \pm 1.11 \mathrm{mg} \cdot \mathrm{L}^{-1}\right)$ with a bottom sediment concentration of $502.8 \pm 91.0 \mathrm{mg} \cdot \mathrm{kg}^{-1}$. The concentration levels of $\mathrm{Mn}$ in overlying water and bottom sediment of the contaminated fishponds were $2.6 \pm 0.60 \mathrm{mg} \cdot \mathrm{L}^{-1}$ and $369.0 \pm 14.15 \mathrm{mg} \cdot \mathrm{kg}^{-1}$, respectively. $\mathrm{Pb}$, a potent toxic pollutant of the environment, was recorded higher in the bottom sediment $(210.4 \pm 30.97 \mathrm{mg} \cdot \mathrm{kg}-1)$ with respect to the overlying water $\left(0.46 \pm 0.16 \mathrm{mg} \cdot \mathrm{L}^{-1}\right)$. The concentration of $\mathrm{Cr}$ and $\mathrm{Cu}$ in overlying water of contaminated ponds were $0.96 \pm 0.29 \mathrm{mg} \cdot \mathrm{L}^{-1}$ and $0.62 \pm 0.31 \mathrm{mg} \cdot \mathrm{L}^{-1}$, respectively.

In the water of uncontaminated fishponds, $\mathrm{Cr}$ concentration was also very low $\left(0.11 \pm 0.01 \mathrm{mg} \cdot \mathrm{L}^{-1}\right)$. However, Fe concentration in water of these ponds was found to be higher $\left(5.9 \pm 1.20 \mathrm{mg} \cdot \mathrm{L}^{-1}\right)$ than that of wastewater fed fishponds.

Table 1

Concentrations of trace metals in water $\left(\mathrm{mg} \cdot \mathrm{L}^{-1} \pm s\right)$ and bottom sediments $\left(\mathrm{mg} \cdot \mathrm{kg}^{-1} \mathrm{dw} \pm s\right)$ collected from both uncontaminated and contaminated (wastewater fed) fishponds

\begin{tabular}{lccccccc}
\hline \multirow{2}{*}{ Fishpond } & \multicolumn{7}{c}{ Element } \\
\cline { 2 - 8 } & \cline { 2 - 8 } & $\mathrm{Cr}$ & $\mathrm{Mn}$ & $\mathrm{Fe}$ & $\mathrm{Cu}$ & $\mathrm{Zn}$ & $\mathrm{Pb}$ \\
\hline \multirow{3}{*}{$\mathrm{W}$} & $\mathrm{U}$ & $0.11 \pm 0.01$ & $0.43 \pm 0.14$ & $5.9 \pm 1.12$ & 0 & $1.8 \pm 0.23$ & 0 \\
& $\mathrm{C}$ & $0.96 \pm 0.29$ & $2.6 \pm 0.60$ & $3.1 \pm 1.12$ & $0.62 \pm 0.31$ & $6.1 \pm 1.11$ & $0.46 \pm 0.16$ \\
$\mathrm{BS}$ & $\mathrm{U}$ & $126.8 \pm 22.56$ & $227.0 \pm 38.14$ & $22580.0 \pm 1201.80$ & $47.3 \pm 11.13$ & $75.8 \pm 10.27$ & $11.2 \pm 2.81$ \\
& $\mathrm{C}$ & $723.0 \pm 97.58$ & $369.0 \pm 14.15$ & $26630.5 \pm 7145.31$ & $212.1 \pm 19.09$ & $502.85 \pm 91.00$ & $210.4 \pm 30.97$ \\
\hline
\end{tabular}

W, water; BS, bottom sediment; U, uncontaminated; C, contaminated

Table 2

Accumulation of trace metals in different body organs of Oreochromis niloticus, collected from both uncontaminated and contaminated (wastewater-fed) fishponds (data expressed in $\mathrm{mg}^{\prime} \mathrm{kg}^{-1} \mathrm{dw} \pm s$ )

\begin{tabular}{lcccccrc}
\hline \multirow{2}{*}{$\begin{array}{l}\text { Tissue } \\
\text { examined }\end{array}$} & \multicolumn{7}{c}{ Element } \\
\cline { 2 - 8 } Gill & $\mathrm{Cr}$ & $4.2 \pm 0.70$ & $106.5 \pm 10.67$ & $622.5 \pm 68.89$ & $7.5 \pm 0.40$ & $624.7 \pm 67.65$ & $3.6 \pm 0.36$ \\
& $\mathrm{C}$ & $7.6 \pm 0.75$ & $73.5 \pm 8.06$ & $1351.1 \pm 234.27$ & $4.2 \pm 0.30$ & $1664.6 \pm 107.35$ & $6.9 \pm 1.02$ \\
\multirow{2}{*}{ Liver } & $\mathrm{U}$ & $11.1 \pm 1.00$ & $19.9 \pm 3.20$ & $996.1 \pm 128.96$ & $33.2 \pm 19.72$ & $1728.3 \pm 351.65$ & $0.73 \pm 0.44$ \\
& $\mathrm{C}$ & $32.1 \pm 3.20$ & $82.7 \pm 5.58$ & $6455.2 \pm 588.46$ & $310.1 \pm 34.76$ & $9908.9 \pm 306.42$ & $17.9 \pm 3.37$ \\
\multirow{2}{*}{ Muscle } & $\mathrm{U}$ & $2.1 \pm 0.66$ & $3.8 \pm 0.30$ & $63.9 \pm 1.20$ & $0.56 \pm 0.30$ & $704.4 \pm 104.83$ & $0.32 \pm 0.16$ \\
& $\mathrm{C}$ & $2.7 \pm 0.47$ & $8.3 \pm 1.17$ & $128.0 \pm 5.35$ & $1.04 \pm 0.19$ & $797.9 \pm 112.02$ & $3.9 \pm 0.32$ \\
Bone & $\mathrm{U}$ & $4.8 \pm 0.80$ & $161.9 \pm 4.60$ & $243.3 \pm 7.11$ & $2.7 \pm 0.32$ & $2620.9 \pm 173.21$ & $0.12 \pm 0.10$ \\
& $\mathrm{C}$ & $6.9 \pm 1.17$ & $159.2 \pm 14.59$ & $166.1 \pm 6.86$ & $5.1 \pm 0.85$ & $4584.4 \pm 237.81$ & $1.6 \pm 0.36$ \\
\hline
\end{tabular}

U, uncontaminated fishpond; C, contaminated fishpond 
Metal concentration in fish tissues: Comparison of metal concentrations of trace elements in gill, liver, muscle, and bone tissues of Oreochromis niloticus and $O$. mossambicus collected from wastewater-fed fishponds were presented in Tables 2, 3 (expressed in $\mathrm{mg} \cdot \mathrm{kg}^{-1}$ of dry weight of the sample). Comparisons of the metal concentrations in the organs of both samples collected from uncontaminated fishponds were also depicted in Tables 2 and 3. It had been found that the accumulation of all the metals in contaminated fish tissues was much higher than that of uncontaminated sample. Variations in the accretion and distribution pattern of different metals in the fish body collected from the study sites were found from the results. Liver was found to be the dominant site for metal accumulation in both species. Interestingly, between the two species, the highest $\left(9908.9 \pm 306.42 \mathrm{mg} \cdot \mathrm{kg}^{-1}\right)$ and lowest $\left(797.9 \pm 112.02 \mathrm{mg} \cdot \mathrm{kg}^{-1}\right)$ concentrations of $\mathrm{Zn}$ had been found in $O$. niloticus liver and muscles, respectively. Similarly, the concentration of $\mathrm{Cr}$, which is a known contaminant in tannery effluents, was found higher in the liver of Nile tilapia $\left(32.1 \pm 3.20 \mathrm{mg} \cdot \mathrm{kg}^{-1}\right)$ than that of Mozambique tilapia $\left(9.4 \pm 0.85 \mathrm{mg} \cdot \mathrm{kg}^{-1}\right)$. However, gill and bone of Mozambique tilapia accumulated higher amounts of $\mathrm{Cr}$ than that of Nile tilapia. $\mathrm{Pb}$, a non-essential toxic element, was accumulated in liver of both the species in highest concentration $\left(17.9 \mathrm{mg} \cdot \mathrm{kg}^{-1}\right.$ in Nileand $14.7 \mathrm{mg} \cdot \mathrm{kg}^{-1}$ in Mozambique tilapia). Bioactive element like Fe showed almost similar accumulation pattern with liver was found as major site followed by gill, bone and muscle. Gill was found to be the major site for $\mathrm{Mn}$ build-up (106.5 $\mathrm{mg} \cdot \mathrm{kg}^{-1}$ in Nile- and $96.5 \mathrm{mg} \cdot \mathrm{kg}^{-1}$ in Mozambique tilapia); however, highest concentration of Mn was found in bones $\left(159.2 \mathrm{mg} \cdot \mathrm{kg}^{-1}\right.$ in Nile- and 180.7 $\mathrm{mg} \cdot \mathrm{kg}^{-1}$ in Mozambique tilapia) of the fish.

Statistical analysis: The factor analysis using Principal Component Model with Varimax rotation followed by Kaiser Normalization was performed (Table 3). Principal Component Matrix (2 components extracted) focused the relative importance of metals in influencing bioconcentrations in fish organs. The highest factor loading (FL) in each component was emphasized; Fe was the principal metal in the first component $(\mathrm{FL}=0.983)$ while $\mathrm{Mn}$ in the second component $(\mathrm{FL}=0.959)$. Dendrograms (Figs. 1,2) constructed on the pooled data i.e., both species of cichlid fish cultivated in both clean and wastewater-fed fisheries, show the relations between toxic metals in respect to the levels of bioconcentrations (Fig. 1) and between different fish organs involved in handling these toxic metals (Fig. 2), with definite pattern of clustering. $\mathrm{Cr}, \mathrm{Pb}, \mathrm{Cu}$, and $\mathrm{Mn}$ were in a single cluster; Fe was nearer to that cluster while $\mathrm{Zn}$ was most distantly placed from the cluster of other five metals.

\section{DISCUSSION}

The higher elemental concentrations bottom sediment of the fishponds was in agreement with the concept that bottom sediments contain higher concentrations of metals than that of overlying water (DePinto and Martin 1980). It was evident from our data that, ratio of concentration of $\mathrm{Mn}$ in overlying water and bottom sediment was quite high in comparison to the ratio (water: sediment) of concentrations other metals of wastewater-fed ponds, which was may be due to element specific rate of sedimentation from the water into the bottom sediment as reported by other authors (Vallius 1999). The rate of sedimentation of different elements were also influenced by different components present in the composite effluents from industries, subsequently resulting in different distribution pattern in sediments and water, which was specific to a particular element (Vulkan et. al. 2002). Organic contents in this environment play an important role in the sedimentation of specific heavy metals in bottom sediments as had been

Table 3

Accumulation of trace metals in different body organs of Oreochromis mossambicus, collected from both uncontaminated and contaminated (wastewater-fed) fishponds (data expressed in $\mathrm{mg} \cdot \mathrm{kg}^{-1} \mathrm{dw} \pm s$ )

\begin{tabular}{|c|c|c|c|c|c|c|c|}
\hline \multirow{2}{*}{\multicolumn{2}{|c|}{$\begin{array}{l}\text { Tissue } \\
\text { examined }\end{array}$}} & \multicolumn{6}{|c|}{ Element } \\
\hline & & $\mathrm{Cr}$ & $\mathrm{Mn}$ & $\mathrm{Fe}$ & $\mathrm{Cu}$ & $\mathrm{Zn}$ & $\mathrm{Pb}$ \\
\hline \multirow{2}{*}{ Gill } & $\mathrm{U}$ & $3.9 \pm 0.70$ & $96.5 \pm 13.44$ & $623.6 \pm 84.97$ & $6.9 \pm 0.35$ & $1260.2 \pm 88.41$ & $4.4 \pm 0.20$ \\
\hline & $\mathrm{C}$ & $10.8 \pm 1.35$ & $56.8 \pm 11.54$ & $1270.6 \pm 246.45$ & $5.9 \pm 0.15$ & $3371.7 \pm 125.02$ & $10.2 \pm 0.90$ \\
\hline \multirow{2}{*}{ Liver } & $\mathrm{U}$ & $5.4 \pm 0.91$ & $13.7 \pm 1.36$ & $683.1 \pm 78.49$ & $41.5 \pm 12.82$ & $2445.6 \pm 416.68$ & $2.6 \pm 1.40$ \\
\hline & $\mathrm{C}$ & $9.4 \pm 0.85$ & $30.4 \pm 5.26$ & $3859.5 \pm 205.17$ & $277.8 \pm 50.99$ & $4410.4 \pm 84.66$ & $14.7 \pm 4.17$ \\
\hline \multirow{2}{*}{ Muscle } & $\mathrm{U}$ & $2.1 \pm 0.25$ & $4.7 \pm 0.61$ & $132.4 \pm 3.53$ & $3.2 \pm 0.36$ & $543.4 \pm 59.77$ & $0.11 \pm 0.09$ \\
\hline & $\mathrm{C}$ & $2.6 \pm 0.20$ & $4.9 \pm 0.80$ & $149.3 \pm 7.58$ & $8.6 \pm 0.55$ & $1686.7 \pm 139.15$ & $3.3 \pm 0.45$ \\
\hline \multirow{2}{*}{ Bone } & $\mathrm{U}$ & $9.9 \pm 0.90$ & $200.2 \pm 17.14$ & $253.2 \pm 21.01$ & $5.9 \pm 0.80$ & $2049.3 \pm 64.44$ & $0.08 \pm 0.07$ \\
\hline & $\mathrm{C}$ & $12.0 \pm 0.85$ & $180.7 \pm 9.67$ & $134.4 \pm 4.31$ & $7.4 \pm 0.66$ & $5423.6 \pm 486.74$ & $1.9 \pm 0.36$ \\
\hline
\end{tabular}

U, uncontaminated fishpond; C, contaminated fishpond 


\section{Rescaled Distance Cluster Combine}

$\begin{array}{lllllll}-\overline{\mathrm{CASE}} & 0 & 5 & 10 & 15 & 20 & 25\end{array}$

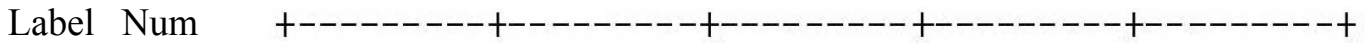

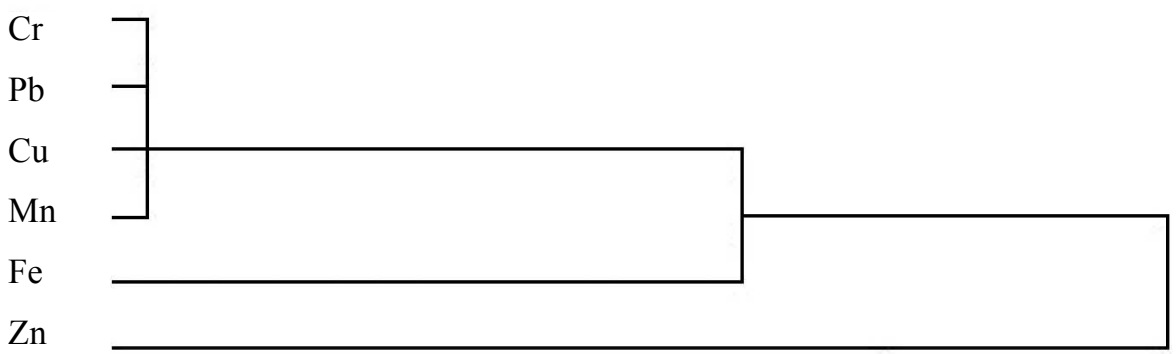

Fig. 1. Dendrogram (using average linkage between groups) constructed on the pooled data i.e., both species of cichlid fish cultivated in both clean and wastewater-fed fisheries to show the relations between toxic metals in respect to the levels of bioconcentrations

\section{Rescaled Distance Cluster Combine}

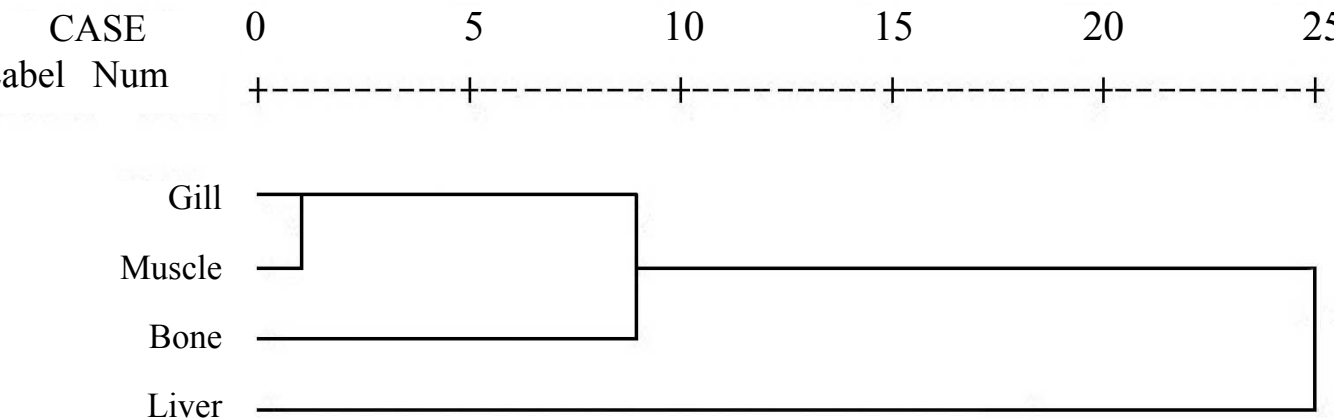

Fig. 2. Dendrogram (using average linkage between groups) constructed on the pooled data i.e., both species of cichlid fish cultivated in both clean and wastewater-fed fisheries to show the relations between different fish organs involved in handling toxic metals

reported by earlier workers (Bryan and Langston 1992). It has been well documented that bottom sediment composition including the metal speciation, nature of complexes, metal-metal interactions and other factors such as temperature, $\mathrm{pH}$, dissolved oxygen and organic ligands, play an

Table 4 activity (as a thermodynamic measure of metal reactivity)

Principal Component Matrix (2 components extracted) to show the relative importance of trace metals in influencing metal bioconcentrations in fish organs

\begin{tabular}{lrr}
\hline Element & \multicolumn{2}{c}{ Component } \\
\cline { 2 - 3 } & \multicolumn{1}{c}{1} & \multicolumn{1}{c}{2} \\
\hline $\mathrm{Fe}$ & 0.983 & -0.174 \\
$\mathrm{Cr}$ & 0.946 & 0.325 \\
$\mathrm{Zn}$ & 0.802 & 0.568 \\
$\mathrm{Cu}$ & 0.968 & -0.129 \\
$\mathrm{Mn}$ & -0.171 & 0.959 \\
$\mathrm{~Pb}$ & 0.856 & -0.353
\end{tabular}

important role in respect to bioavailability of elements and concentration in tissue level of the consumer organisms (Campbell et al. 1997, Zhang et al. 1997). Metal speciation between dissolved and particulate phases and competitive interactions play a major role in bio-availability of metal, which was a function of free metal concentration or than the total metal concentration (Anderson and Morel 1982, Morel 1986) For example, metal toxicity of $\mathrm{Cu}$ to algae becomes more pronounced if the organisms are stressed by Mn limitation (Sunda and Huntsman 1983). Thus, bioaccumulation is the result of competing rates of chemical uptake and elimination (Veith et al. 1979, Barron 2003).

According to Factor analysis using Principal Component Model data, metal ions like, $\mathrm{Mn}$ and Fe were probably playing key role uptake and accumulation of the organisms. These metal ions possibly compete with other toxic and/or bio-inactive metal ions influencing the bioconcentration of the metals in fish organs, which was also reported by van Ginneken et al. (1999). 
Dendrograms showed the relationships between toxic metals with respect to the levels of bioconcentrations and among fish organs involved in processing these toxic metals, with a definite clustering pattern, gill and muscle in one cluster while bone and liver, two important organs so far as partitioning (in bone) and detoxification (in liver) were concerned, appeared in two separate clusters as fish was observed to be an excellent bioaccumulator (Olsson 1998).

Concentrations of heavy metals in fish tissues were always higher than that of water (Chale 2002). Entry of metal occurs either through gill membrane or through ingestion. A difference in metal accumulation in different fish organs, as indicated by our study, was also reported by Mathis and Cummings (1973), Kalay and Canli (2000), Bury et al. (2003). Accumulation of bioactive metals like $\mathrm{Fe}, \mathrm{Mn}, \mathrm{Cu}$, and $\mathrm{Zn}$ was actively controlled by the fish through different metabolic processes and the level of accumulations usually independent of ambient concentrations. On the other hand, environmental concentrations affect the accumulation of non-essential toxic elements like $\mathrm{Pb}$ (Pattee and Pain 2003). Bioactive metals play important role in metabolism, thus in physiology and pathology of fish. Metals like $\mathrm{Zn}, \mathrm{Cu}$, or $\mathrm{Mn}$ function as a cofactor in several enzyme systems (Bury et al. 2003) while Fe is directly involved with haemoglobin formation in fish blood. However, when in excessively high concentrations, these bioactive metals may pose serious threats to normal metabolic processes.

In fish, gills are considered to be the dominant site for contaminant uptake because of their anatomical and/or physiological properties that maximize absorption efficiency from water (Hayton and Barron 1990). However, it was evident from our study that, in general, either bone or liver was the site of maximum accumulation for the elements while muscle was the over all site of least metal accumulation in both the species. As described by other workers (Rema and Babu 1997, Thaker et al. 1997), osteoblasts in bones were important centres for the formation of metal-complexes and thereby, immobilize and storing them. Considerable amounts of $\mathrm{Fe}$ and $\mathrm{Pb}$ were also present in gills of both the fish species collected from the contaminated site. The lower concentration of $\mathrm{Cu}$ in the gill than that of muscles and livers was possibly due to lower binding affinity of $\mathrm{Cu}$ on the gill surface. This was in good conformity with the speculation of Reid and McDonald (1991) who proposed that $\mathrm{Cu}$ had a greater likelihood of entering the fish tissues rather than binding on the gills as it was a lower-binding affinity metal. However, species-specific patterns of metal concentration were apparent from our experimentation.

\section{CONCLUSION}

The composite industrial and municipal effluents (about 68 million $\mathrm{L} \cdot \mathrm{day}^{-1}$ ) were being utilized for pisciculture in the East Calcutta Wetlands, which is unique in production of 'wealth from waste' (Patnaik 1990). It was evident from our study that potentially hazardous metal contaminants in the tissues of fish cultured in contaminated area of both cichlids were higher in concentration levels in the tissues than that of fish of the uncontaminated area. In metal contaminated aquatic environment, common method employed by the organism like fish, include methylation of the metal which reduces its toxicity within the system; the storing of the metal as a metalloprotein complex in which the protein (usually thionein) binds the metal firmly and thereby detoxifies it, resulting in its concentration in various organs of the fish. Liver, which play most important role in metal detoxification processes with the help of several such metalloproteins including metallothionein, (Dang et al. 1999), therefore constituting high metal concentration, manifested by our study.

\section{ACKNOWLEDGEMENTS}

Authors thankfully acknowledge AICTE and UGCDAE, CSR, Calcutta Centre, India for financial supports. The authors also express gratitude to the Director, UGCDAE, CSR, Calcutta Centre, Calcutta, India, Director of Technical Education and the Director of Public Instructions, Govt. of West Bengal, India for cooperation and necessary support.

\section{REFERENCES}

Anderson D.M., Morel F.M.M. 1982. The influence of aqueous iron chemistry on the uptake of iron by the coastal diatom Thalassiosira weissflogii. Limnology and Oceanography 27: 789-813.

Barron M.G. 2003. Bioaccumulation and bioconcentration in aquatic organisms. Pp. 877-892. In: Hoffman D.J., Rattner B.A., Burton jr. G.A., Cairns jr. J. (eds.) Handbook of ecotoxicology. 2nd edn. Lewis Publishers, Boca Raton, Florida.

Bryan G.W., Langston W.J. 1992. Bioavailability, accumulation and effects of heavy metals in sediments with special reference to United Kingdom estuaries: A review. Environmental Pollution 76: 89-131.

Bury N.R., Walker P.A., Glover C.N. 2003. Nutritive metal uptake in teleost fish. Journal of Experimental Biology 206: 11-23.

Campbell P.G.C., Twiss M.R., Wilkinson K.J. 1997. Accumulation of natural organic matter on the surfaces of living cells: Implications for the interaction of toxic solutes with aquatic biota. Canadian Journal of Fisheries and Aquatic Science 54: 2543-2554.

Canli M., Erdem C. 1994. Mercury toxicity and effects of exposure concentration and period on mercury accumulation in tissues of a tropical fish Tilapia niloticus (L.). Turkish Journal of Zoology 18: 233-239.

Chale F.M. 2002. Trace metal concentrations in water, sediments and fish tissue from Lake Tanganyika. Science of Total Environment 299: 115-121.

Chattopadhyay B., Chatterjee A., Mukhopadhyay S.K. 2002. Bioaccumulation of metals in the East Calcutta Wetland Ecosystem. Aquatic Ecosystem Health and Management 5 (2): 191-203.

Dang Z., Lock R.A.C., Flik G., Bonga S.E.W. 1999. Metallothionein response in gills of Oreochromis mos- 
sambicus exposed to copper in fresh water. American Journal of Physiology - Regulatory, Integrative and Comparative Physiology 277: 320-331.

DePinto J.V., Martin S.C. 1980. Aquatic sediments. Journal of the Water Pollution Control Federation 52: 1656-1670.

van Ginneken L., Chowdhury M.J., Blust R. 1999. Bioavailibility of cadmium and zinc to the common carp, Cyprinus carpio, in complexing environments: a test for the validity of the free ion activity model. Environmental Toxicology and Chemistry 18: 2295 2304.

Hayton W.L., Barron M.G. 1990. Rate-limiting barriers to xenobiotic uptake by the gill. Environmental Toxicology and Chemistry 9: 151-157.

Isaac R.A., Kerber J.D. 1971. Atomic absorption and flame photometry: Technique and uses in soil, plant and water analysis. Pp. 17-37. In: Walsh L.M. (ed.) Instrumental methods for analysis of soils and plant tissue. Soil Science Society of America, Madison WI.

Jana S., Sahana S.S. 1988. Effects of copper, cadmium and chromium cations on the freshwater fish Clarias batrachus L. Physiologia Bohemoslovaca 37: 79-82.

Kalay M., Canli M. 2000. Elimination of essential $(\mathrm{Cu}$, $\mathrm{Zn})$ and non-essential $(\mathrm{Cd}, \mathrm{Pb})$ metals from tissues of a freshwater fish Tilapia zilli. Turkish Journal of Zoology 24: 429-436.

Lin T.S., Lin C.S., Chang C.L. 2005. Trace elements in cultured tilapia (Oreochromis mossambicus): Results from a farm in southern Taiwan. Bulletin of Environmental Contamination and Toxicology 74: 308-313.

Mahmood G. 2003. Lead and nickel concentrations in fish and water of River Ravi. Pakistan Journal of Biological Sciences 6: 1027-1029.

Mathis B.J., Cummings T.F. 1973. Selected metals in sediments, water and biota in the Illinois River. Journal of the Water Pollution Control Federation 45: 1573-1583.

Morel F.M.M. 1986. Trace metal-phytoplankton interaction: An overview. Pp. 117-189. In: Lasserre P., Martin J.M. (eds.) Biogeochemical processes at the land-sea boundary. Elsevier, Amsterdam.

Olsson P.E. 1998. Disorders associated with heavy metal pollution. Pp. 105-131. In: Leatherland J.F., Woo P.T.K. (eds.) Fish diseases and disorders. Vol. II. Noninfectious disorders. CABI Publishing, Wallingford, UK.

Patnaik A.K. 1990. An action plan for the development of the Calcutta sewage-fed fish pond system. Pp. 119-124. In: Edwards P., Pullin R.S.V. (eds.) Wastewater-fed aquaculture. Proceedings of the International Seminar on Wastewater Reclamation and Reuse for Aquaculture, Calcutta, India, 6-9 December 1988, ENSIC, Asian Institute of Technology, Bangkok, Thailand.
Pattee O.H., Pain D.J. 2003. Lead in the environment. Pp. 373-408. In: Hoffman D.J., Rattner B.A., Burton jr. G.A., Cairns jr. J. (eds.) Handbook of ecotoxicology. 2nd edn. Lewis Publishers, Boca Raton, FL.

Pillay T.V.R. 1993. Aquaculture - principles and practices. Fishing News Books, London.

Reid S.D., McDonald D.G. 1991. Metal binding activity of the gills of rainbow trout (Oncorhynchus mykiss). Canadian Journal of Fisheries and Aquatic Science 48: 1061-1068.

Rema L.P., Babu P. 1997. Accumulation of an essential metal (zinc) and a non-essential metal (mercury) in different tissues of Oreochromis mossambicus (Peters). Indian Journal Experimental Biology 35: 67-69.

Sunda W.G., Huntsman S.A. 1983. Effect of competitive interaction between manganese and copper on cellular manganese and growth in estuarine and oceanic species of the diatom Thalassiosira. Limnology Oceanography 28: 923-924.

Thaker J., Chhaya J., Mittal R., Nuzhat S., Mansuri A.P., Kundu R. 1997. Dose and duration dependent toxicity of $\mathrm{Cr}$ (VI) on acid and alkaline phosphatases in six vital organs of mudskipper Periophthalmus dipes. Indian Journal Experimental Biology 35: 397-400.

Vallius H. 1999. Heavy metal deposition and variation in sedimentation rate within a sedimentary basin in central Gulf of Finland. Chemosphere 38: 1959-1972.

Veith G.D., DeFoe D.L., Bergstedt B.V. 1979. Measuring and estimating the bioconcentration factor of chemicals in fish. Journal of the Fisheries Research Board of Canada 36: 1040-1048.

Vulkan R., Mingelgrin U., Ben-Asher J., Frenkel H. 2002. Copper and zinc speciation in the solution of a soil-sludge mixture. Journal of Environmental Quality 31: 193-203.

Welz B., Sperling M. 1999. Atomic Absorption Spectrometry. 3rd edn. Wiley-VCH, Weinheim.

Wong M.H. 2003. Ecological restoration of mine degraded soils, with emphasis on metal contaminated soils. Chemosphere 50: 775-780.

Zhang M., Alva A.K., Li Y.C., Calvert C.V. 1997. Fractionation of iron, manganese, aluminium [si and phosphorus in selected sandy soils under citrus production. Soil Science Society of America Journal 61: 794-801.
Received: 17 April 2006 Accepted: 21 January 2007 Published electronically: 10 February 2007 